\title{
THE IMPACT OF THE COVID-19 PANDEMIC ON HEALTH AND SOCIO- ECONOMIC FACTORS IN SERBIA AND THE ANALYSIS OF THE LEGISLATIVE RESPONSE OF THE STATE
}

\begin{abstract}
The pandemic of the disease caused by Covid-19 has been of unprecedented proportions thus far. The spread of the virus has an extremely invasive effect on all aspects of human life and activity around the planet. According to the fact that this is a novel virus still spreading, and whose effects are significantly reflected on people's everyday life and activity, its full dimension and consequences have not yet been fully understood. Regarding the issue itself, this scientific paper reviews the impact of the Covid-19 pandemic on the health systems of Serbia and the Western Balkans region as well as the impact of the pandemic on socioeconomic factors in Serbia. Furthermore, there is a brief analysis of the legislative response of Serbia in the field of protection of the population from infectious diseases, as well as in the field of prescribing mandatory preventive measures for labor safety and health. It also includes the prevention of the occurrence and spread of epidemics of infectious diseases in the work environment.
\end{abstract}

Keywords: Covid-19, Health System, socio-economic questions, the Criminal Code, The Law on Protection of the Population from Infectious Diseases

\footnotetext{
* LLD, A Full Professor, The Faculty of Law for Commerce and Judiciary in Novi Sad, The University of Business Academy in Novi Sad, Serbia, e-mail: jelena@pravni-fakultet.info

${ }^{* *}$ LLM, A PhD candidate at the Faculty of Law for Commerce and Judiciary in Novi Sad, The University of Business Academy in Novi Sad, Serbia, e-mail: stefan.ditrih@pravni-fakultet.info
} 


\section{Introduction}

The pandemic of the disease caused by the virus Covid-19 is of unprecedented proportions. The spread of the virus has an extremely invasive effect on all aspects of human life and activity around the planet. What attracts the attention of not only the professional but also the general public is the impact of Covid-19 on health factors, as well as socio-economic factors in modern society because it seems that these vital segments are most exposed to Covid-19, and thus record daily immeasurable losses. The pandemic caused by the Covid-19 virus and all the measures applied in response to it, both in the world and in Serbia, have an extremely strong effect on many aspects of the daily life of the population.

According to the International Labor Organization - ILO (2020), "it is estimated that the number of working hours decreased by $4.5 \%$ globally in the first quarter of 2020, which is equivalent to 130 million full-time jobs. 2020. In the second quarter, the number of global working hours was $10.5 \%$ lower than in the pre-crisis quarter, which is equivalent to 305 million full-time jobs. The largest drop in this regard was in North, Central and South America $(12.4 \%)$, as well as Europe and Central Asia (11.8\%). Vulnerable categories in the labor market are particularly susceptive to the effects of the pandemic. This primarily includes informal employees, of which there are an estimated 1.6 billion in the world. It is also estimated that the relative poverty rate in this category will increase by $34 \%$ "(pp. 1-2).

Firstly, according to the data of the World Health Organization - WHO (2020a), the first registered case in the world was recorded in China, on January 7th, 2020; the first registered case in Europe was recorded in France, on January 24th, 2020. (WHO, 2020b), and WHO (2020c) declared a pandemic on March 11th, 2020.

According to a study dealing with the impact of the pandemic on employment and working conditions, "the response to the pandemic in Serbia initially followed a "restrictive model," which included a slew of measures such as closing the borders, stopping public transport to reduce human mobility, relatively high restrictions on movement during periods of curfew and several days of lock-down. These measures, also, included the closure of all retail stores except grocery stores, relocation of work from offices to employees' homes except in cases when it is not possible or in case of essential workers, closure of educational institutions at all levels, cancelation of public and social services in direct contact with citizens, etc" (Group of authors, 2020, p. 7).

The paper will continue to explore, in more detail, the impact of Covid-19 on health factors in the region, especially the challenges that the health systems 
of Serbia and the Western Balkans have faced since the beginning of the pandemic. Then, the impact of the Covid-19 pandemic on socio-economic factors in Serbia will be analyzed, bearing in mind that the measures taken during the pandemic mostly affect the at-risk population. Not only did the vast number of people live in poverty before the outbreak of Covid-19, but their situation was further exacerbated by restrictive response measures to the virus. Finally, one chapter of the paper will be dedicated to the analysis of the legislative treatment of protection of the population from infectious diseases, and the prescription of obligatory preventive measures aimed at a safe and healthy work environment and prevention of the occurrence and spread of infectious diseases in the work environment.

\section{Impact of Covid-19 on Health Systems of Serbia and the Western Balkans Region}

According to the estimates of the Global Health Security Index - GHS Index, the countries of the Western Balkans were relatively well ranked on the international list of preparedness to respond to the pandemic, at the very beginning of the outbreak of Covid-9 (GHS Index, 2020). The criteria used for these assessments were primarily the readiness of the state health system to prevent and detect sources of infection, respond quickly to current challenges, and respect international standards. It should be noted that the Global Health Security Index is the first comprehensive assessment of global health care capabilities in 195 countries (GHS Index, 2020). ${ }^{1}$ However, according to a study published by the World Bank Group, "health systems in the Western Balkans faced serious challenges even before the outbreak of the Covid-19 pandemic" (World Bank Group, 2020, p. 2).

The next two tables will analyze the value of the Global Health Security Index of countries in the Region, and their health systems in 2019, also according to the GHSI.

\footnotetext{
${ }_{1}$ „A total of 140 questions from the Global Health Safety Index are organized into six categories: prevention (prevention of occurance or release of pathogens), detection and reporting (early detection and reporting of epidemics of potential international importance), rapid response (rapid response and mitigation of the epidemic), health system (sufficient and robust health system for the treatment of the sick and protection of health workers), compliance with international standards (commitment to improving national capacities, funding plans to address deficiencies and adherence to global standards), risky environment (general risk environment and vulnerability of the country to biological threats)“.
} 
Table 1. Value of the Global Health Security Index of the countries of the Region

\begin{tabular}{|l|c|c|c|c|c|}
\hline GHSI value & Albania & $\begin{array}{c}\text { Bosnia and } \\
\text { Herzegovina }\end{array}$ & Montenegro & North Macedonia & Serbia \\
\hline Rank & $39 / 195$ & $79 / 195$ & $68 / 195$ & $90 / 195$ & $41 / 195$ \\
\hline Mark & 52,9 & 42,8 & 43,7 & 39,1 & 52,3 \\
\hline Prevention & 43,8 & 36,7 & 37,6 & 37 & 48,8 \\
\hline Detection & 74,3 & 41,7 & 77,3 & 41,7 & 46,2 \\
\hline Response & 52 & 51,8 & 37,8 & 33,1 & 55,1 \\
\hline Health System & 35,9 & 38,3 & 30,8 & 25,4 & 56,5 \\
\hline Standards & 53 & 37,8 & 52,6 & 44,8 & 49,7 \\
\hline Risk & 55,7 & 50,8 & 60,8 & 57,7 & 59,2 \\
\hline
\end{tabular}

Source: World Bank Group (2020)., p. 3.

Analyzing the data in the table, which includes the value of the Global Health Safety Index, it can be concluded that "although all five countries covered by the GHSI survey in 2019 are placed in the first half of the rankings, the resilience of the health system and its capacity to treat patients and protect health workers is recognized as a weak point of the entire Region "(World Bank Group, 2020, p. 3).

Table 2. Analysis of Health Systems, Global Health Security Index in 2019.

\begin{tabular}{|l|c|c|c|c|c|}
\hline & Albania & $\begin{array}{c}\text { Bosnia and } \\
\text { Herzegovina }\end{array}$ & Montenegro & $\begin{array}{c}\text { North } \\
\text { Macedonia }\end{array}$ & Serbia \\
\hline $\begin{array}{l}\text { Capacity of clinical } \\
\text { centers, hospitals } \\
\text { and health centers to } \\
\text { provide health care }\end{array}$ & 10,8 & 15,1 & 23,1 & 42,2 & 19,4 \\
\hline $\begin{array}{l}\text { Medical countermeasures } \\
\text { and task management }\end{array}$ & 33,3 & $\mathbf{0}$ & 33,3 & $\mathbf{0}$ & 33,3 \\
\hline Access to health care & 30 & 47,7 & 31,9 & 47,6 & 45,9 \\
\hline $\begin{array}{l}\text { Communication with } \\
\text { health workers in } \\
\text { case of public health } \\
\text { emergency }\end{array}$ & 100 & 50 & $\mathbf{0}$ & $\mathbf{0}$ & 50 \\
\hline $\begin{array}{l}\text { Infection control policy } \\
\text { and equipment availability }\end{array}$ & $\mathbf{0}$ & 50 & 50 & $\mathbf{0}$ & 100 \\
\hline $\begin{array}{l}\text { Capacity to test and } \\
\text { approve new medical } \\
\text { countermeasures }\end{array}$ & 50 & 75 & 50 & 75 & 100 \\
\hline
\end{tabular}

Note: Grades are displayed on a scale from 0 to 100 , with 100 being the highest grade. Marked cells represent the lowest scores for each country, which should be considered the highest priority.

Source: World Bank Group (2020)., p. 8. 
After the data analysis, what certainly emerges as a general conclusion is that special attention should be paid to the areas analyzed in the table, not only during the Covid-19 pandemic but also after the pandemic is over. In particular, the following should be taken into account: "investments should be made in responsiveness to pandemics and public health systems to stop transmission; recognize the impact of deep recessions on health budgets and fiscal space; minimize financial risk for patients in need of health care to protect at-risk patients; ensure continuity of service delivery and explore opportunities for sustainable innovation, recover to a level considered a new normal" (World Bank Group, 2020, pp. 8-12).

\section{The Effect of the Covid-19 pandemic on socio-economic factors in Serbia}

The pandemic and its consequences represent an enormous challenge not only in terms of the timely response of the health system but also in the socio-economic segment of society, bearing in mind that the consequences of Covid-19 occur quickly and have both, long-term economic and social consequences. In Serbia, the pandemic itself and the measures taken by the Government in response to it, had a strong effect on the economy, the work of institutions, the availability of public and social services, but also on the daily life of the population. According to a UNICEF study, "the socio-economic impact of Covid-19 will be felt most by those already at risk. Many who are already living in poverty, as the consequences of the response to Covid-19, run the risk of further endangerment of their situation" (UNICEF, 2020a, p. 6).

Another UNICEF study dealing with the impact of the Covid-19 pandemic on families with children in Serbia points out that "the crisis caused by the Covid-19 pandemic has significantly affected incomes of household with children, almost half (47\%) of these households witnessed a drop in income during the pandemic. Among households whose incomes were reduced, in $39 \%$ of the cases, there was a decrease of up to $30 \%$, a third reported a decrease between $31 \%$ and $50 \%$ in household income, while almost a fifth $(18 \%)$ stated that their household income decreased by more than $50 \%$. When observing the total target population, $18 \%$ of households with children under 17 suffered a decrease in household income by up to $30 \%, 15 \%$ of households suffered a decrease in household income by $31 \%-50 \%$, and $8 \%$ of households faced an income decrease of more than 50\%" (UNICEF, 2020b, p. 7). 
Table 3. Impact of the Covid-19 pandemic on household income

\begin{tabular}{|c|c|c|}
\hline & \multicolumn{2}{|c|}{ Does the situation with Covid-19 affect household income? } \\
\hline No & \multicolumn{2}{|c|}{$51 \%$} \\
\hline Yes, income growth & \multicolumn{2}{|c|}{$2 \%$} \\
\hline \multirow{6}{*}{ Yes, income decrease } & \multicolumn{2}{|c|}{$47 \%$} \\
\hline & \multicolumn{2}{|c|}{ Percentage of the decrease in income } \\
\hline & Up to $30 \%$ & $39 \%$ \\
\hline & $31 \%-50 \%$ & $31 \%$ \\
\hline & More than $50 \%$ & $18 \%$ \\
\hline & Refused to answer & $12 \%$ \\
\hline
\end{tabular}

Source: UNICEF (2020b)., p. 7.

Certainly one of the most sensitive existential issue is the impact of the Covid-19 pandemic on job loss.

According to a study conducted by SeCons \& Friedrich Ebert Stiftung, "in April 2020, 8\% of people who were employed in February 2020 in the non-agricultural sector lost their jobs. When this percentage is projected on the total population, it amounts to approximately 200,000 people who lost their jobs after the declaration of the state of emergency, including the informally employed" (Grup of authors, 2020, p. 10). Furthermore, "almost half of the people who lost their jobs (46.2\%) stated that the reason for the loss of employment was that their company had to suspend activities due to the Covid-19 pandemic. One-fifth of employees whose contracts have expired during the state of emergency were not offered contract renewal, which could also be the effect of a pandemic and employers' fear of upcoming economic trends. In addition, about a quarter of surveyed individuals stated that they lost their jobs because they could not arrange transportation to work or had to give priority to babysitting children who could not go to kindergarten/school, or because of elderly people in their household who depend on other people's care, but now could not get that care from state institutions or organizations" (Group of Authors, 2020, p. 10).

The following table shows the numerical percentage data on the reasons for job loss in Serbia during the Covid-19 pandemic. 
Table 4. Percentual data on the reasons for job loss in Serbia during the Covid-19 pandemic

\begin{tabular}{|c|l|c|}
\hline & Reasons for job loss & $\mathbf{\%}$ \\
\hline 1 & They were fired due to the suspension of the company's activity & 46,2 \\
\hline 2 & Their contract expired and no new one was offered & 20,5 \\
\hline 3 & People who quit because they have to take care of children or the elderly & 12,1 \\
\hline 4 & Fired for other reasons & 5,3 \\
\hline 5 & Fired of quit because they couldn't get to work & 10,6 \\
\hline 6 & Other & 5,3 \\
\hline
\end{tabular}

Source: Group of Authors (2020)., p. 11.

According to the same study, "the biggest impact on job loss was present with people employed in the private sector, primarily in catering, construction, then people who are self-employed but do not employ other workers, as well as informally employed people. Observed by occupations, most of the persons who lost their jobs worked in the commerce and service industry, but the share of experts, officials, construction workers, as well as workers who perform simple occupations is not negligible. Gender differences are not statistically significant"(Group of Authors, 2020, p. 11).

Moreover, "job losses have hit the private sector much harder than the public sector. Only $3.4 \%$ of employees in the public sector lost their jobs, while in the private and mixed sectors $10 \%$ of employees lost their jobs. Interestingly, no one in the public sector had to quit because they had to take care of children or the elderly in the household. On the other hand, the share of those who lost their jobs due to the expiration of their contract is higher in the public sector than in the private sector (35.3\% and $21.8 \%$ respectively). In the new situation, vulnerable categories of employees were particularly affected: those who work without contracts, those who work with occasional contracts, then with fixedterm contracts, as well as the entrepreneurs without employed workers" (Group of Authors, 2020, p. 12). It is interesting to note certain socio-demographic characteristics of job loss during the Covid-19 pandemic, so the next two tables will present data indicating the percentage tendencies of job loss according to statistical regions, as well as job loss according to age categories.

Table 5. Percentual tendencies of job loss according to statistical regions in Serbia

\begin{tabular}{|c|l|c|}
\hline & Regions & $\mathbf{\%}$ \\
\hline 1 & Belgrade & 8,2 \\
\hline 2 & Vojvodina & 6,6 \\
\hline 3 & West Serbia and Šumadija & 9 \\
\hline 4. & South and East Serbia & 9,3 \\
\hline
\end{tabular}

Source: Group of Authors (2020)., p. 14. 
Thus, it can be seen that the Covid-19 pandemic and the measures taken in response to it affected almost equally all regions in Serbia. Although the impact was somewhat smaller in Vojvodina, the difference is not statistically significant.

Table 6. Percentual tendencies of job loss according to age categories in Serbia

\begin{tabular}{|c|l|c|}
\hline & Age group & $\mathbf{\%}$ \\
\hline 1 & $18-29$ & 12,6 \\
\hline 2 & $30-39$ & 9,2 \\
\hline 3 & $40-49$ & 6,1 \\
\hline 4 & $50-59$ & 7 \\
\hline 5 & $60+$ & 6,3 \\
\hline
\end{tabular}

Source: Group of Authors (2020)., p. 15.

Therefore, it can be seen that during the Covid-19 pandemic in Serbia and the measures taken in response to it, young people were more likely to lose their jobs than older employees, which may be explained by the fact that young people are more often employed in industries that were hit the hardest.

In addition to some relevant reviews made in the analysis of the impact of the Covid-19 pandemic on the health systems of Serbia and the Western Balkans, and the impact of the pandemic on socio-economic factors in Serbia, the issue of the legislative response of the state is important (in this case the Republic of Serbia). Most importantly state's action or inaction in certain cases that are essential for an adequate understanding of the issue and providing a timely response of the state to the challenges in this situation. In the context of the above-mentioned, the next chapter will deal with a review of the laws in Serbia which, with their content, completely or in a certain part regulated vital issues in the field of the legislative response of our country when it comes to protection from infectious diseases. It is important to note that the timely legislative reaction of the state is in a direct interactive relationship with both health and socioeconomic factors.

\section{Legislative response of the State in the field of protection of the population from infectious diseases}

The effects of the Covid-19 pandemic on health and socio-economic factors in Serbia have consequently been reflected on the state's legislative response when it comes to the protection of the population from infectious diseases, as well as in prescribing mandatory preventive measures for a safe 
and healthy work environment and preventing the outbreak and spread of the epidemic in the work environment.

The Law on the Protection of the Population from Infectious Diseases (2016) was amended after the outbreak of Covid-19. This Law regulates various protection issues and rules as regards the preservation of the population against contagious diseases, including specific health issues, rules regarding the infectious diseases that can endanger the health of the population, and whose prevention and suppression is of general interest for the Republic of Serbia, further setting the implementation of epidemiological surveillance and monitoring measures, and various security requirements useful for such scope. Article 3, paragraph 1 of the Law stipulates that the protection of the population from infectious diseases is an organized and all-encompassing activity of the society to prevent and combat infectious diseases, as well as their elimination and eradication. Article 4 of the Law stipulates that infectious diseases include: diseases that lead or may lead to significant illness and/or death, especially those whose prevention requires broader coordination of activities; diseases where the exchange of information can provide early warning for threats to public health; rare and serious infectious diseases, which are not present in the Republic of Serbia, and for which grouping of data may indicate the factors responsible for their outbreak; diseases for which there are effective prevention measures for the benefit of the population; diseases in which comparing the frequency of occurrence with other environments can contribute to the assessment and improvement of programs for the protection of the population from infectious diseases. The law prescribes the rights, obligations, and competencies in the implementation of protection of the population from infectious diseases, as well as measures for the protection of the population from infectious diseases and the modalities of their implementation. In this context, Article 14 stipulates that measures undertaken to protect the population from infectious diseases are a set of all activities planned, organized, and implemented by the authorities of the Republic of Serbia, autonomous provinces, local governments, businesses, and legal entities, institutes and public health institutions and other health care institutions, health workers and health associates and natural persons to protect the population from infectious diseases. Protection of the population from infectious diseases is performed by implementing general, special, emergency, and other measures for the protection of the population from infectious diseases.

In addition to the mentioned law, the legislator included two criminal offenses connected to infectious diseases in the Criminal Code (2005), in the chapter dealing with criminal offenses against human health (Chapter XXIII). 
Failure to Act Pursuant to Health Regulations during an Epidemic (Article 248) and Transmitting Contagious Disease (Article 249).

According to Article 248 of the Criminal Code, "Whoever during an epidemic of a dangerous contagious disease fails to act pursuant to regulations, decisions or orders setting forth measures for suppression or prevention thereof, shall be punished by fine or imprisonment up to three years." Furthermore, under article 249 of the Criminal Code, "Whoever during an epidemic of a dangerous contagious disease fails to act pursuant to regulations, decisions or orders setting forth measures for suppression or prevention thereof, shall be punished by fine or imprisonment up to three years". It should also be noted that Article 259 of the Criminal Code (serious offenses against human health) in paragraphs 1 and 2 prescribes that "If due to offense of Transmitting Contagious Disease, a person sustains grievous bodily harm or serious health impairment, the offender shall be punished by imprisonment of one to eight years", or if the same offense "results in the death of one or more persons, the offender shall be punished by imprisonment of two to twelve years."

When it comes to preventive measures for a safe and healthy work environment, and prevention of outbreaks and spread of infectious diseases in the work environment, the Minister of Labor, Employment, Veterans and Social Affairs on July 3, 2020, based on the Law on Safety and Health at Work (2005) passed the Rulebook on Preventive Measures for Safe and Healthy Work to Prevent the Occurrence and Spread of Epidemics of Infectious Diseases (2020). This Rulebook prescribes preventive measures that the employer is obliged to apply to prevent the occurrence and spread of infectious diseases and eliminate risks for safe and healthy work of employees, as well as persons present in the work environment, in the case when a competent authority declares an epidemic of infectious diseases. It is applied at all workplaces in the work environment where the actual work is performed, except for fieldwork and work from home (Articles 1 and 2 of the Rulebook). According to Article 3 of the Ordinance, the employer is obliged to, for all jobs in the work environment, adopt a Plan for the implementation of measures to prevent the outbreak and spread of an epidemic of an infectious disease, which is an integral part of the Risk assessment act, in accordance to labor laws on health and safety. The employer is obliged to harmonize the Plan of application of necessary measures, due to the changes that affect safe and healthy work during the epidemic, with the decisions of the competent authority.

Article 4 stipulates that the Implementation plan sets out measures and activities that increase and improve the safety and health of employees to prevent the outbreak of infectious disease, as well as measures and activities 
taken in the event of an outbreak of an infectious disease to maintain a safe and healthy work environment for all employees and the protection of those present at the workplace. Consequently, the Implementation plan must contain: 1) preventive measures and activities aimed at preventing the outbreak of an infectious disease; 2) persons responsible for the implementation and control of the implementation of preventive measures and activities; 3 ) measures and activities for action in case of an outbreak of an infectious disease. In addition to the above-mentioned, Article 8 of the Rulebook prescribes the obligations of the employee in the application of safety and health measures at work to preserve his health, as well as the health of other employees.

\section{Conclusion}

Every day we learn more about the effects of Covid-19 on human life around the planet. Considering that this is a novel virus that is still expanding, and whose effects are very much reflected on everyday life and work of people, its full dimension has not yet been understood. In other words, apart from the knowledge that the virus is in a state of a pandemic, and that it continuously reflects negatively on almost all aspects of human life and work around the planet, we are just guessing the real scope of Covid-19, its full capacity, a possible response to future potential immunization, and a true picture of the consequences (both material and immaterial), of which we are probably not even remotely aware at this time.The paper explores and reviews the impact of the Covid-19 pandemic on the health systems of Serbia and the Western Balkans region, and the impact of the pandemic on socio-economic factors in Serbia. Also, in short, the legislative response of Serbia in the field of protection of the population from infectious diseases, as well as in the field of prescribing mandatory preventive measures for safe and healthy work, and prevention of outbreaks and spread of epidemics of infectious diseases in the work environment, is given.

There is no doubt that the consequences of the presence of Covid-19, but also the implementation of all state measures to prevent the spread of the virus significantly affect the health system (mostly in the domain of its accelerated improvement to respond as adequately as possible to the growing number of infected people), then to social and economic issues (issues of social deprivation in case of loss of employment, or greater or lesser reduction in wages, are extremely important, and greatly affect the population of all ages), but also on the legislative concept which, following its role, must keep pace with societal events (in this segment, existing laws and bylaws are being 
amended and potential strategic steps in this area are being undertaken as the pandemic is still going on).

\section{Matijašević Jelena}

Redovni profesor, Pravni fakultet za privredu i pravosuđe u Novom Sadu, Univerzitet Privredna akademija u Novom Sadu, Srbija

\section{Ditrih Stefan}

Master pravnik, doktorand, Pravni fakultet za privredu i pravosuđe u Novom Sadu, Univerzitet Privredna akademija u Novom Sadu, Srbija

\section{UTICAJ PANDEMIJE COVID-19 NA ZDRAVSTVENE I SOCIO-EKONOMSKE ASPEKTE U SRBIJI I ANALIZA LEGISLATIVNOG ODGOVORA DRŽAVE}

REZIME: Pandemija bolesti koju izaziva Covid-19 je nezapamćenih razmera. Širenje virusa izuzetno invazivno utiče na sve aspekte života i rada ljudi šrom planete. S obzirom na to da se radi o novom virusu koji je još uvek u ekspanziji, i čiji se efekti značajno svakodnevno odražavaju na život i rad ljudi, još uvek nije u potpunosti sagledana njegova potpuna dimenzija ni posledice. Shodno problematici, u radu su učinjeni određeni osvrti na uticaj pandemije Covid-19 na zdravstvene sisteme Srbije i region Zapadnog Balkana, te uticaj pandemije na socio-ekonomske aspekte u Srbiji. Takođe, u kraćim crtama, analiziran je i legislativni odgovor Srbije u domenu zaštite stanovništva od zaraznih bolesti, kao i u oblasti propisivanja obaveznih preventivnih mera za bezbedan i zdrav rad, te za sprečavanje pojave i širenja epidemije zarazne bolesti u radnoj okolini.

Ključne reči: Covid-19, zdravstveni sistem, socio-ekonomska pitanja, Krivični zakonik, Zakon o zaštiti stanovništva od zaraznih bolesti. 


\section{References}

1. Grupa autora (2020). Covid-19 i zaposlenost u Srbiji: uticaj pandemije $i$ mera za njeno sprečavanje na zaposlenost $i$ uslove rada žena i muškaraca $u$ Srbiji [Covid-19 and employment in Serbia: the impact of the pandemic and measures for its prevention on employment and working conditionsof men and women in Serbia]. Beograd: SeCons - development initiative group, Friedrich Ebert Stiftung

2. GHS Index. Downloaded 2020, July 01 from https://www.ghsindex.org/

3. International Labour Organization (2020). ILO Monitor: COVID-19 and the world of work - Updated estimates and analysis (Third edition). Downloaded 2020, July 05 from https:/www.ilo.org/wcmsp5/groups/ public/---dgreports/---dcomm/documents/briefingnote/wcms_743146. pdf

4. Krivični zakonik [Criminal Law]. Službeni glasnik $R S$, no. 85/05, 88/05 - ispr., 107/05 - ispr., 72/09, 111/09, 121/12, 104/13, 108/14, 94/16 and $35 / 19$

5. Pravilnik o preventivnim merama za bezbedan i zdrav rad za sprečavanje pojave i širenja epidemije zarazne bolesti [Rulebook on preventive measures for safe and healthy work to prevent the occurrence and spread of epidemics of infectious diseases]. Službeni glasnik $R S$, no. 94/20

6. UNICEF (2020a). UNICEF-ov odgovor na pandemiju Covid-19 u Srbiji [UNICEF's response to the Covid-19 pandemic in Serbia]. Beograd: UNICEF Srbija

7. UNICEF (2020b). Istraživanje o uticaju pandemije Covid-19 na porodice sa decom u Srbiji [Research on the impact of the Covid-19 pandemic on families with children in Serbia]. Beograd: USAID \& UNICEF Srbija

8. World Health Organization (2020a). Coronavirus disease (COVID-19) outbreak. Downloaded 2020, July 10 from http://www.euro.who. $\mathrm{int/en/health-topics/health-emergencies/coronavirus-covid-19/}$ novel-coronavirus-2019-ncov

9. World Health Organization (2020b). 2019-nCoV outbreak: first cases confirmed in Europe. Downloaded 2020, January 10 from http://www. euro.who.int/en/health-topics/health-emergencies/coronavirus-covid-19/ news/news/2020/01/2019-ncovoutbreak-first-cases-confirmed-in-europe

10. World Health Organization(2020c). Healthemergencies. Downloaded2020, July 10 from http://www.euro.who.int/en/health-topics/healthemergencies 
11. World Bank Group (2020). Ekonomski i socijalni uticaj Covid-19-zdravstveni sistemi [Economic and social impact Covid-19 - health systems]. Redovni ekonomski izveštaj za Zapadni Balkan, no. 17

12. Zakon o zaštiti stanovništva od zaraznih bolesti [Law on Protection of the Population from Infectious Diseases]. Službeni glasnik RS, no. 15/16 and $68 / 20$

13. Zakon o bezbednosti i zdravlju na radu [Law on Safety and Health at Work]. Službeni glasnik RS, no. 101/05, 91/15 and 113/17 - and other law 